\title{
Problematika Pembelajaran Pendidikan Agama Islam Melalui Microsoft Teams Pada Masa Pandemi
}

\author{
M. Abdul Wahid Ulya \\ Teacher SMA Negeri 1 Bringin and Program Pascasarjana Institut Agama Islam Negeri \\ Salatiga, Jawa Tengah, Indonesia \\ Email: mabdulwahidulya@gmail.com
}

\begin{abstract}
This research is the outcome of an analysis of the problematics of learning Islamic religious education at the time of the pandemic through Microsoft Teams at Bringin 1 Senior High School with 807 students. The objective of this study is to identify the issues experienced by the students during online learning. This research employed qualitative approach in order to assists researcher in obtaining data regarding student difficulties. Furthermore, the researcher used the purposive sampling technique to obtain significant results that reflected the entire number of students, and the researcher discovered that the most common issue faced by students was difficulty in understanding the material through virtual meetings, which contributed for $47.3 \%$ of the total. Moreover, there was the experience of being constrained by signals and networks, which contributed for $30,4 \%$, followed by a sense of laziness related to online or e-learning, which contributed for $18,9 \%$, and feeling burdened by practical religious obligations, which contributed for $2,7 \%$, and eventually the lack of spiritual motivation from teachers, which contributed for $0,7 \%$.
\end{abstract}

Keywords: Problematics, Islamic Religious Education Learning, Microsoft Teams, Pandemic Period

\section{PENDAHULUAN}

Pada tahun 2020 ini, semua negara sedang mengalami masa pandemi dikarenakan adanya sebuah virus yang disebut dengan virus corona 19 sehingga menyebabkan sistem pendidikan mengalami perubahan yang semula dapat dilakukan dengan cara tatap muka dikelas yang selanjutnya berganti menjadi pembelajaran jarak jauh yang disebut dengan sistem daring. Dimana negara Indonesia pun melaksanakan pembelajaran melalui sistem daring di berbagai daerah dengan bantuan teknologi berbasis internet (Adisel, 2020). Pembelajaran yang dilakukan dengan cara daring merupakan hal baru dalam proses belajar dan mengajar dimana pada mekanisme pelaksanaanya memanfaatkan media elektronik terkhusus jaringan internet. Pembelajaran yang dilakukan dengan cara daring ini juga dinilai menjadi satu-satunya media dalam menyampaikan materi dari pendidik ke peserta didik dalam masa pandemi (Rigianti, 2020). Hal tersebut menjadikan seorang pendidik harus menguasai berbagai platform pembelajaran, sosial media maupun teknologi informasi masa sekarang dalam arus globalisasi supaya mampu beradaptasi dengan keadaan yang ada serta tetap mampu melakukan pembelajaran secara efektif.

Pada saat ini, sosial media serta teknologi informasi sangatlah cepat dan pesat dalam perkembangannya, dimana hal tersebut sudah masuk ke berbagai komponen kehidupan manusia seperti pada bidang pendidikan. Teknologi informasi dan komunikasi sangat mempunyai peran penting dalam dunia pendidikan hingga mampu memberikan kontribusi yang sangat tinggi terhadap sistem pendidikan serta mampu meningkatkan proses dalam pembelajaran (William, 2015). Berdasarkan hal itu, seorang pendidik harus mampu menguasai 
teknologi informasi agar mampu mengadakan pembelajaran yang efektif pada masa pandemi sekarang ini. Dimana hal tersebut memunculkan berbagai pilihan media yang akan digunakan oleh seorang pendidik. Salah satu media yang di rekomendasikan oleh pemerintah seperti pada tingkat Dinas Pendidikan Jawa Tengah untuk jenjang sekolah menengah atas adalah melalui aplikasi Microsoft Teams yang mana sebelumnya telah ada pelatihan bagi para pendidik yang disebut dengan Training of Trainers (TOT) pada tanggal 29 sampai 30 Juli, 3 sampai 4 Agustus dan 10 Agustus 2020.

Microsoft Teams adalah aplikasi digital yang terhubung dengan cloud serta mampu menyatukan percakapan, rapat, file, dan aplikasi dalam satu Sistem Manajemen Pembelajaran (LMS) (Microsoft, 2018). Aplikasi tersebut memiliki fitur yang sangat banyak dan lengkap serta mampu untuk membantu meningkatkan pembelajaran di masa pandemi. Tidak hanya itu, pihak Microsoft pun memberikan penggunaan aplikasi tersebut pada dunia pendidikan secara gratis (edu-techno.com). Dalam hal ini, pendidik sangat memiliki peran penting dalam kegiatan mengajar serta ketika ada perubahan pola belajar, dimana pada masa pandemi ini harus merubah ke bentuk pembelajaran online (daring). Oleh karena itu, seorang pendidik diwajibkan memiliki fleksibilitas dalam berbagai kondisi pembelajaran, keadaan peserta didik, serta yang memiliki kaitan dengan masyarakat dalam hal perkembangan (Wahyono, 2020).

Pembelajaran online seluruhnya memang memiliki banyak manfaat bagi peserta didik apalagi pada masa pandemi seperti ini, sebab mereka mampu belajar dimana dan kapan saja serta sesuai dengan kecepatan mereka. Hal itu menunjukkan dampak yang positif dengan adanya bukti sebuah karya-karya (Alqurashi, 2019). Namun, dalam pembelajaran daring menggunakan aplikasi Microsoft Teams meski sudah memiliki banyak fitur untuk menunjang pembelajaran, khususnya pada mata pelajaran pendidikan agama islam pastinya memiliki berbagai problematika. Dikarenakan kurangnya interkasi diantara pendidik dan peserta didik yang menyebabkan perlambatan dalam pembentukan values di dalam proses belajar-mengajar (Hilna, 2020). Padahal dalam pembelajaran agama islam selalu ada praktik ibadah dan keterampilan mengenai amaliyah keagamaan. Hal tersebut juga mempengaruhi terhadap psikologi dan budi pekerti para peserta didik, dimana akibat kurangnya interaksi dengan pendidik serta praktik keagamaan membuat turunnya budi pekerti serta moralitas peserta didik. Selaras dengan pernyataan Wilatikta bahwa peserta didik dituntut supaya dapat memahami dan mengerti materi pembelajaran, dimana hal itu tidak bisa dilakukan hanya melalui aspek kognitif. Sebab peserta didik harus hadir supaya mampu menumbuhkan aspek afektif dan mengembangkan psikomotoriknya (Wilatikta, 2020).

Penelitian ini sangat penting dilakukan, karena peneliti ingin mengetahui masalah apa saja yang dihadapi dalam pembelajaran pendidikan agama islam dengan menggunakan sistem daring khusunya melalui aplikasi Microsoft Teams. Dimana pembelajaran pendidikan agama islam membutuhkan banyak sekali interaksi sosial serta praktik agar peserta didik memahami dengan betul ilmu yang disampaikan. Peneliti juga berharap agar hasil penelitian ini dapat membantu para pendidik mengetahui masalah-masalah yang dihadapi dalam pembelajaran daring pada materi pendidikan agama islam khususnya menggunakan aplikasi Microsoft Teams sehingga mereka mampu memperbaiki proses pembelajaran hingga menemukan solusisolusi yang paling tepat dengan problematika yang sedang dihadapinnya serta meningkatkan ke-efektifan dalam kegiatan pembelajaran.

\section{KONSEP TEORI}

Dalam Journal At-Thariqah (Susiana, 2017) Problem adalah sebuah masalah atau persoalan. Pada pembelajaran agama islam seringkali ditemukan adanya banyak permasalahan dari berbagai aspek dalam pembelajaran yang mengakibatkan terhambat untuk mencapai tujuan 
secara maksimal. Pendidikan agama berasal dari kata majemuk "pendidikan" dan "agama". Pendidikan sendiri memiliki makna adanya proses perubahan sikap dalam upaya mendewasakan manusia melalui pengajaran dan latihan. Sedangkan makna agama adalah suatu kepercayaan pada Tuhan yang ada ajaran kebaktian serta suatu kewajiban yang berhubungan dengan kepercayaan tersebut. Pendidikan agama islam sendiri merupakan sebuah kesadaran oleh generasi tua (pendidik) untuk mengarahkan pengalaman, pengetahuan, kecakapan dan keterampilan kepada generasi muda (peserta didik) supaya menjadi manusia muslim, berbudi luhur dan bertakwa kepada Allah swt serta mampu mengamalkan ajaran-ajaran islam pada kehidupan sehari-hari.

Dengan demikian dapat dijelaskan bahwa problematika pembelajaran pendidikan agama islam merupakan sebuah masalah ataupun persoalan yang ditemukan pada proses pembelajaran baik dari aspek pendidik, peserta didik, metode maupun media yang digunakan dalam penyampaian materi agama islam yang mengakibatkan tidak tercapainya tujuan secara maksimal yang bersifat keagamaan, kepribadian yang luhur dan implementasi ajaran keagamaan dalam kehidupan sehari-hari.

\section{METODE PENELITIAN}

Peneliti melakukan penelitiannya mulai bulan Agustus pada tanggal 10, tahun 2020 sampai bulan Januari pada tanggal 27, tahun 2021 di SMA Negeri 1 Bringin, Kab. Semarang Jawa Tengah. Dimana penelitian tersebut membahas hal-hal yang berkaitan dengan beberapa temuan mengenai adanya problematika yang dihadapi peserta didik dalam pembelajaran daring menggunakan Microsoft Teams. Penelitian ini dilakukan dengan cara pendekatan kualitatif, sehingga peneliti mampu mengetahui dengan tepat dan seksama variabel yang diambil. Kemudian subjek yang digunakan dalam mengambil ataupun menggali data yang akan diteliti terdiri dari peserta didik, wali murid dan pendidik yang berada di SMA Negeri 1 Bringin.

Sugiyono mengatakan bahwa penelitian kualitatif dilakukan terhadap objek yang bersifat alamiah serta mempunyai perkembangan yang apa adanya tanpa dimanipulasi peneliti (Sugiyono, 2015: 15). Kemudian, peneliti itu menjadi instrumen dalam penelitian jenis kualitatif (Sugiyono, 2013: 305). Sebab, manusia itu sendiri menjadi instrumen paling tepat dalam memahami tentang kenyataan yang ada ketimbang instrument lainnya (Mahmud, 2011: 90). Peneliti mengambil data-data mengenai problematika yang sedang dihadapi peserta didik melalui wawancara secara langsung dan daring dengan peserta didik dan wali murid, selain itu adanya beberapa keluhan langsung yang disampaikan ke pihak wali kelas serta guru pendamping maupun guru BK (bimbingan dan konseling). Yang menjadi domain dalam penelitian ini adalah problematika pembelajaran melalui Microsot Teams, pendidik, dan peserta didik dalam sistem pembelajaran secara daring pada masa pandemi. Jumlah semua responden dari peserta didik SMA Negeri 1 Bringin berjumlah 807 siswa, kemudian peneliti melakukan pengambilan informasi dan data dengan cara purposive sampling, yaitu dengan cara mempertimbangkan data-data tertentu dalam pengambilannya, kemudian pengumpulan datanya dilakukan melalui cara dokumentasi (Sugiyono, 2015: 300). Dengan dokumentasi maka peneliti memiliki kesempatan untuk membuka serta memperluas pengetahuan mengenai hal yang diteliti (Sedarmayanti, 2002: 86). Berdasarkan hal tersebut peneliti mengambil datadata untuk dikerucutkan dengan cara sampling melalui google form sebanyak 148 responden yang terdiri dari beberapa tingkat rombel mulai kelas X, XI, dan XII supaya mendapatkan datadata mengenai problematika yang paling sering dihadapi peserta didik. 


\section{HASIL DAN PEMBAHASAN}

Dalam pembelajaran para pendidik diwajibkan memiliki tujuan yang sesuai dengan indikator yang sudah tertera di silabus. Karena keberhasilan pada pembelajaran dapat dilihat dari tercapainya tujuan atau tidak. Terlebih lagi, dalam pembelajaran pendidikan agama islam sangatlah memiliki banyak tujuan yang bersifat mulia serta berhubungan dengan rohani dan budi pekerti. Majid menyatakan bahwa tujuan pendidikan agama islam ialah untuk menumbuhkan serta meningkatkan keimanan dengan pemberian serta pemupukan pengetahuan, penghayatan, pengamalan serta pengalaman guna mengembangkan keimanan, ketakwaan, berbangsa dan bernegara sehingga mampu meneruskan ke derajat yang lebih mulia (Majid, 2004: 135). Selain itu, dalam pendidikan agama islam juga mempunyai nuansa moral dan religious serta tidak mengabaikan persoalan yang bersifat duniawi. Berdasarkan hal tersebut seorang pendidik diwajibkan memiliki niat untuk mendekatkan diri kepada Allah dalam mendidik peserta didik hingga mampu menjadi tauladan bagi mereka. Pendidik juga harus memiliki kompetensi yang baik seperti menguasai materi, berperilaku objektif hingga memberikan perlakuan yang baik pada peserta didik seperti anaknya sendiri (Putra, 2016). Pada aktivitas pembelajaran pendidikan agama islam juga mengacu pada pencarian akan adanya Sang Pencipta, sehingga pendidikan yang bernuansa islami diyakini mampu memberikan pengaruh yang besar dalam perkembangan dunia pendidikan dikarenakan memiliki prinsipprinsip seperti budi pekerti, kemanusiaan yang bersifat soial dan kerjasama, persaudaraan, keadilan, kemerdekaan serta kesempatan yang sama (Harahap dkk, 2017).

Pada kenyataannya, setiap dalam aktivitas pembelajaran tidak selalu berjalan dengan lancar, terkadang ditemukan problem masalah yang dihadapi baik oleh pendidik maupun peserta didik sehingga hal tersebut menjadi hambatan untuk tergapainya suatu tujuan pendidikan. Selaras dengan pernyataan Bukran bahwa problematika pembelajaran merupakan salah satu perkara yang menghalangi aktivitas pembelajaran dengan munculnya suatu hambatan dan persoalan yang belum bisa diselesaikan oleh pendidik ketika melakukan pembelajaran. Problematika pembelajaran itu sendiri dapat diketahui melalui kegiatan pembelajaran yang sedang berlangsung (Bukran, 2017). Begitu juga dalam pembelajaran pendidikan agama islam selalu ditemukan berbagai macam problematika, dimana problematika tersebut menjadi sebuah hambatan untuk mencapai tujuan pembelajaran secara maksimal dimana terdiri dari berbagai aspek (Susiana, 2017). Pada masa pandemi seperti sekarang ini, pembelajaran pendidikan agama islam lebih banyak dilakukan dengan cara daring melalui berbagai media virtual seperti Google classroom, whatsapp, youtube, schology, sampai aplikasi yang berbayar seperti zoom dan Microsoft teams.

Pembelajaran secara daring memang memiliki berbagai dampak positif, namun terlepas dari itu juga memiliki dampak negatif. Perubahan dalam proses pembelajaran dari tatap muka ke pembelajaran secara online memang menimbulkan berbagai bentuk respon serta kendala dalam dunia pendidikan di Indonesia, seperti yang di alami para pendidik pun memiliki kendalanya sendiri-sendiri (Rigianti, 2020). Dalam journalnya yang berjudul "The Problems of Application of Online Learning in the Affective and Psychomotor Domains During the Covid-19 Pandemic", Bali dan Musrifah mengatakan bahwa aplikasi pembelajaran online juga mengakibatkan munculnya masalah pada fasilitas dan fitur yang dimilikinya, dimana hal itu akan mempengaruhi pada bidang afektif maupun psikomotorik peserta didik seperti pada minat belajar, sikap jujur dan tanggung jawab serta kedisplinan. Selain itu, pembelajaran online menjadi lebih membosankan ketika pendidik hanya menggunakan metode yang sama berulang kali setiap hari karena metode pengajaran yang digunakan selama proses pembelajaran online sangat berbeda dari metode belajar konvensional (Bali dan Musrifah, 2020). Sehingga mengakibatkan peserta didik mengalami berbagai kendala dalam mengikuti proses 
pembelajaran pada masa pandemi. Pada penelitian ini, peneliti memfokuskan penelitiannya terhadap masalah yang di alami peserta didik dalam pembelajaran online menggunakan aplikasi Microsoft teams pada materi pendidikan agama islam. Microsoft teams sendiri memiliki banyak fitur serta terdiri dari beberapa saluran yang digunakan untuk membagi Teams ke dalam beberapa topik. Martin juga mengatakan bahwa dengan teams, pendidik dan peserta didik mampu melakukan kolaboratif dalam pembelajaran yang mana dapat memfasilitasi mereka untuk dapat melakukan presentasi menggunakan power point, kemudian juga dapat dijadikan sebagai media penilaian sebuah tugas maupun latihan secara terstruktur dan formatif (Martin, 2019).

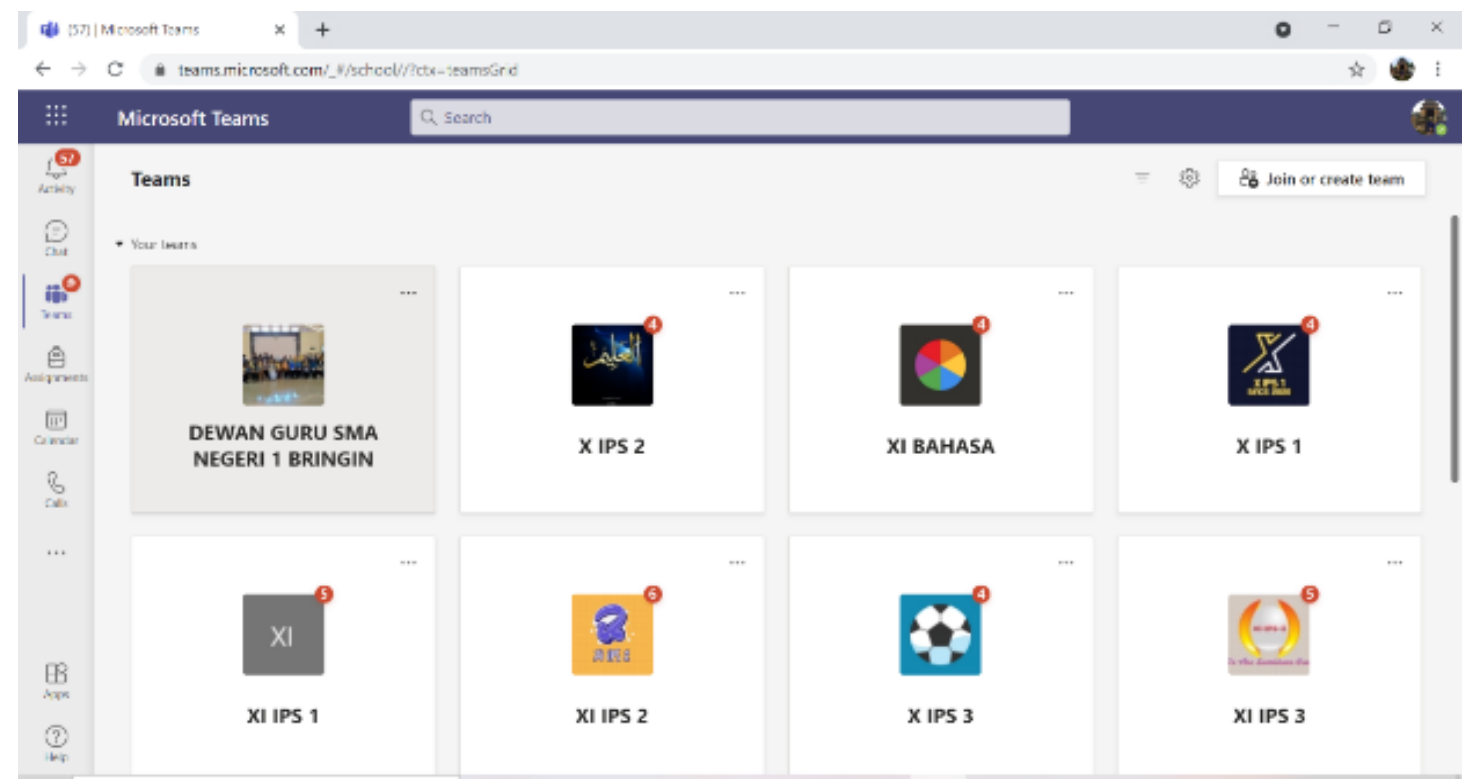

Gambar 1. Screenshot tampilan Microsoft Teams 2020

Kemudian dalam kegiatan pembelajaran tersebut, masih ditemukan beberapa masalah yang menyebabkan kurang efektifnya pembelajaran dimana terdapat beberapa peserta didik yang belum memiliki smartphone serta sibuknya orang tua yang fokus pada pekerjaan mereka. Padahal orang tua juga memiliki peran serta yang penting dalam mengawasi dan membimbing anak mereka supaya tidak timbul rasa malas dan tetap semangat meski belajar dari rumah (Hilna, 2020). Berdasarkan hal tersebut, pembelajaran pendidikan agama islam juga harus mendapatkan dukungan moral maupun spiritual yang penuh dari orang tua, sebab dalam pembelajaran agama islam sangat berbeda dengan materi yang lain dikarenakan memiliki aspek yang lebih banyak dan bersifat ruhaninyah. Peneliti menemukan problem yang sangat signifikan dilapangan bahwa mayoritas orang tua peserta didik bekerja sebagai buruh pabrik dan petani di ladang sehingga pengawasan terhadap peserta didik sangatlah minim. Hal itu menimbulkan beberapa problematika masalah yang berkelanjutan seperti kemalasan para peserta didik hingga menurunnya budi pekerti yang dimiliki.

Penelitian ini dilakukan dengan instrumen pendekatan kualitatif serta dibantu dengan data-data yang ditemukan peneliti secara langsung, dikarenakan peneliti merupakan pendidik agama islam di sekolah tersebut sehingga mampu mengetahui dengan betul aspek masalah apa saja yang dihadapi siswa dalam pembelajaran pendidikan agama islam dengan sistem daring melalui aplikasi Microsoft teams. Peneliti mengambil beberapa sampel dari keseluruhan jumlah peserta didik yang ada di SMA Negeri 1 Bringin, dengan jumlah seluruh peserta didik pada tahun pelajaran 2020/2021 ini mencapai 807 peserta didik yang terbagi menjadi tiga tingkat yaitu kelas sepuluh berjumlah 277 siswa, kelas sebelas berjumlah 281 siswa dan kelas 
dua belas berjumlah 249 siswa. Nugrahani mengatakan bahwa dalam pendekatan kualitatif pengambilan sampel tidak berdasarkan jumlah, namun mempertimbangkan pemilihan informasi supaya jauh mendapatkan data yang lebih representative (Nugrahani, 2014: 55). Peneliti mengambil sampel dari setiap tingkatan yang data-datanya mewakili setiap tingkatan yang mampu menunjukkan problematika yang sedang dihadapi seluruh peserta didik. Ali juga mengatakan bahwa penelitian dengan menggunakan cara penyempelan tertentu hanya memerlukan waktu yang lebih sedikit ketimbang penelitian populasi (Ali, 1987: 28). Hal tersebut sesuai dengan keadaan pada masa sekarang, dimana akibat pandemi menimbulkan adanya pembatasan waktu serta pertemuan untuk interakasi secara langsung dengan peserta didik menjadi berkurang. Berdasarkan hal itu, peneliti mendapatkan beberapa data sampel dari responden sebagai berikut:

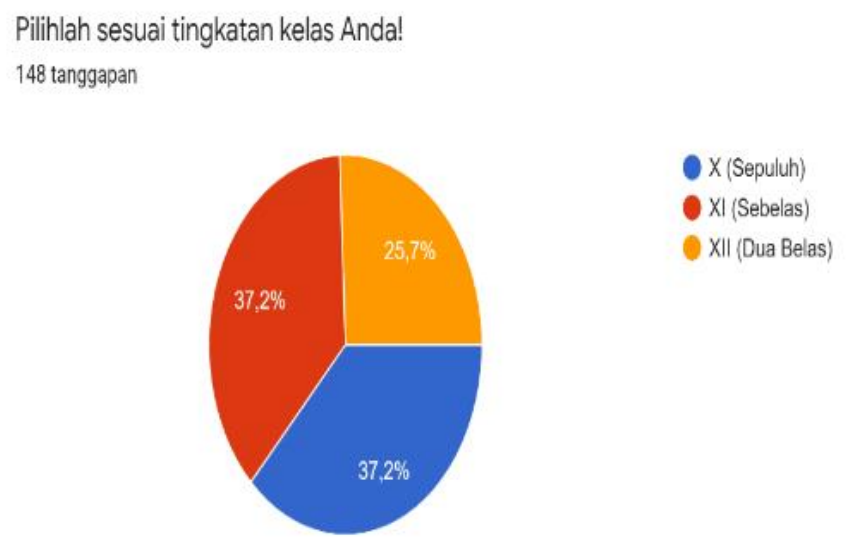

Gambar 2. Sampel Responden dari Google Form

Berdasarkan prosentase diagram data diatas dapat dipaparkan bahwa untuk tingkatan kelas sepuluh mencapai jumlah $37,2 \%$, dan kelas sebelas berjumlah $37,2 \%$ serta kelas dua belas berjumlah 25,7\% dengan jumlah keseluruhan mencapai 148 responden. Jumlah tersebut merupakan hasil sampel dari setiap tingkatan, dimana hal tersebut menunjukkan perwakilan dari banyaknya problem serta masalah yang sedang dihadapi dalam pembelajaran pendidikan agama islam melalui aplikasi Microsoft teams. Kemudian peneliti mengklasifikasikan beberapa problematika yang dihadapi peserta didik, dimana hal itu diperolehnya melalui instrumen langsung dan sesuai dengan kenyataan yang ada dilapangan seperti pengaduan dari peserta didik, pengamatan, keluhan orang tua serta analisis suatu fakta yang bersifat kontemporer. Sehingga ada beberapa problematika yang ditemukan peneliti dalam penelitiannya, diantaranya seperti kesulitan memahami materi melalui virtual meeting, tidak mempunyai laptop atau smartphone, merasa terbebani dengan tugas keagamaan yang bersifat praktik, terkendala sinyal atau jaringan, minimnya dorongan spiritual dari pendidik, tidak memahami penggunaan aplikasi Microsoft teams, kurangnya motivasi dan peran serta dari orang tua dan timbulnya rasa kemalasan karena daring atau e-learning. Adapun problematika pembelajaran tersebut dapat dituangkan dalam diagram dibawah ini: 


\section{Apa saja problematika atau masalah yang anda hadapi dan alami dalam pembelajaran Pendidikan Agama Islam sistem daring melalui aplikasi Microsoft Teams? 148 tanggapan}
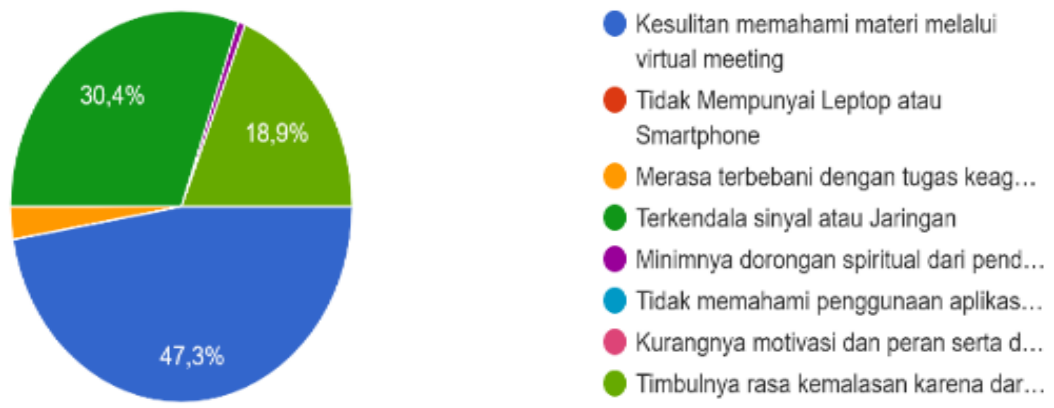

Gambar 3. Hasil responden dari Google Form

Berdasarkan diagram data diatas, banyak sekali problematika serta masalah yang dihadapi pendidik dan peserta didik dalam proses pembelajaran di masa pandemi, khususnya dalam pembelajaran pendidikan agama islam di SMA Negeri 1 Bringin yang menggunakan media pembelajaran berupa aplikasi Microsoft teams. Peneliti akan menjelaskan berbagai problematika mendasar dan yang paling sering dihadapi oleh peserta didik dalam kegiatan belajar dengan penjelasan sebagai berikut:

Yang pertama, kesulitan memahami materi melalui virtual meeting berjumlah 47,3\%. Pendidik dalam melaksanakan pembelajaran harus mampu mengelola kelas dengan baik, selain itu juga harus memiliki media serta sumber belajar yang mudah dipahami (Maulena, 2018). Pada masa pandemi ini, semua pembelajaran dilakukan dengan cara e-learning atau biasa disebut daring yang membuat pendidik maupun peserta didik melakukan pembelajaran dengan cara virtual meeting, faktor tersebut juga mengharuskan seorang pendidik supaya mampu mencari jalan keluar agar dapat menyusun serta membuat bahan ajar berupa materi yang berbasis elektronik dimana mereka akan menggunakan teknologi maupun media terkini (Chiou, 2018). Hal tersebut membuat seorang pendidik harus mampu menguasai berbagai media pembelajaran online yang bersifat kontemporer dan mudah di operasikan oleh pendidik maupun peserta didik sehingga mereka mampu melakukan pembelajaran dengan efektif supaya materinya mudah dipahami oleh peserta didik. Berdasarkan prosentase tersebut, maka dapat di paparkan bahwa peserta didik banyak mengeluhkan pembelajaran pendidikan agama islam melalui sistem virtual meeting, dikarenakan susahnya memahami materi keagamaan yang diberikan. Dalam materi keagamaan tidak hanya bersifat teori saja, namun lebih banyak ke praktikum seperti materi mengenai haji, zakat, wakaf, muamalah dan lain sebagainya sehingga peserta didik tidak bisa melakukan praktik secara langsung serta melakukan kolaborasi dengan pendidik melalui interaksi tatap muka yang mampu membantu peserta didik ketika melakukan kesalahan dalam praktik, yang mana hal tersebut membantu pendidik untuk bisa langsung menegur dan membenarkan kesalahan melalui contoh dan gerakan secara nyata, sehingga peserta didik mampu memperhatikannya dengan seksama dan teliti. Hal itu diperlukannya sebuah stimulus langsung dari pendidik terhadap peserta didik supaya terjadi sebuah interaksi sosial secara langsung tanpa timbulnya sebuah salah paham serta kekeliruan dalam memahami materi yang disampaikan.

Kedua, terkendala sinyal dan jaringan berjumlah 30,4\%. Peserta didik tidak akan mampu mengakses serta mengikuti pembelajaran pada materi yang diberikan oleh pendidik 
jikalau jaringan internet saja tidak begitu memadai, dikarenakan lancarnya suatu jaringan internet menjadi salah satu faktor paling penting serta utama agar pembelajaran secara daring berjalan dengan lancar (Yana, 2020). Pembelajaran yang dilakukan dengan cara daring juga harus mampu memanfaatkan jaringan internet yang stabil saat materi pembelajaran sedang disampaikan (Rigianti, 2020). Hal tersebut sangat berpengaruh sekali pada media yang akan digunakan, jikalau medianya sangat bagus namun terkendala jaringan internet maka yang akan terjadi hanya akan menimbulkan masalah baru yaitu tidak bisanya tersambung dengan media yang digunakan dalam pembelajaran daring. Selain itu, ada beberapa peserta didik yang tidak bisa mengikuti pembelajaran melalui virtual meeting dikarenakan terkendala sinyal. Keaktifan mereka dalam pembelajaran online ini dapat diperhatikan dari beberapa hal seperti saat mengerjakan tugas (Nurhayati, 2020). Selain mengerjakan tugas juga dapat dilihat dari kedisiplinan mereka saat mengumpulkan tugas dan hadir saat diadakan pertemuan pembelajaran secara online. Sekolah SMA Negeri 1 Bringin berlokasi di daerah pinggiran, bukan terletak dikota besar sehingga melalui sistem zonasi menjadikan mayoritas peserta didiknya berasal dari pedesaan yang terkadang belum terjangkau oleh sinyal internet. Selain itu, akses data jaringan seperti wifi masih belum sampai ke daerah yang terletak ditengahtengah hutan jati, bukit-bukit serta jauh dari akses jalan utama. Hal tersebut menyebabkan siswa sulit mengakses materi pendidikan agama islam, dimana mereka belum sampai mengetahui isi materi secara kompleks sudah kesulitan terlebih dahulu dalam hal menyambungkan laptop atau smartphone ke paket data maupun jaringan internet. Kejadian ini tidak akan pernah ditemukan ketika pembelajaran dilakukan di dalam kelas, karena siswa bisa langsung mengakses materi yang disampaikan tanpa melalui perantara media virtual.

Ketiga, timbulnya rasa kemalasan karena daring atau e-learning berjumlah 18,9\%. Masa pandemi covid-19 memiliki beberapa dampak negatif pada dunia pendidikan, dimana salah satunya adalah timbulnya rasa malas pada peserta didik. Rasa malas yang dialami peserta didik saat pembelajaran daring bukanlah suatu hal yang mudah diuraikan, masalah tersebut harus mampu di pahami secara menyeluruh dalam hal mencari faktor apa saja yang menjadi penyebab timbulnya rasa malas tersebut sehingga seorang pendidik mampu mencari solusi untuk menanganinya. Faktor penyebab kemalsan seorang peserta didik pastinya sangat berbeda-beda yang terdiri dari faktor internal maupun faktor eksternal. Faktor internal kemalasan peserta didik muncul akibat tidak adanya dukungan dari dalam diri serta semangat yang dapat mengakibatkan turunnya kekuatan fisik serta psikis yang akan melemah, hal tersebut akan memunculkan perasaan malas pada peserta didik (Fahruni, 2021). Peserta didik juga mudah terganggu psikis serta mental karena berbagai faktor, baik faktor lingkungan, kurangnya dukungan orang tua, teman serta lainnya. Mereka terbiasa melakukan interaksi dengan teman-temannya saat disekolah, berbeda dengan sekarang yang harus terbiasa dengan keadaan menyendiri dirumah. Hal itu menjadikan peserta didik mudah murung dan marah serta mengalami perubahan perasaan yang tidak biasa, disini orang tua memiliki peran yang sangat penting untuk membantu memberikan semangat kepada anak-anak mereka (Sonia, 2020). Oleh karena itu, motivasi serta dorongan pada peserta didik sangatlah penting dikarenakan setiap peserta didik memiliki dua unsur konsep motivasi yang terdiri dari motivasi intrinsik yang datang dari dalam dirinya sendiri serta motivasi ekstrinsik yang berasal dari orang lain. Kemudian motivasi ekstrinsik sangat dibutuhkan sekali oleh peserta didik saat ia tidak memiliki motivasi dari dalam dirinya (Tabi'in, 2016). Untuk mengatasi berbagai masalah yang menjadi latar belakang timbulnya sifat kemalasan pada peserta didik tersebut, semua unsur yang terlibat dalam proses pembelajaran harus bekerjasama secara optimal dan saling memberikan dorongan motivasi supaya dapat mencapai tujuan pembelajaran yang maksimal.

Ke-empat, merasa terbebani dengan tugas keagamaan yang bersifat praktik berjumlah $2,7 \%$. Ketika pembelajaran dilakukan di dalam kelas, peserta didik mampu melakukan 
berbagai diskusi serta bekerja sama dengan temannya dalam mengerjakan tugas mereka, dimana mereka akan saling membantu satu sama lain. Akan tetapi, pada pembelajaran yang dilakukan secara daring membuat mereka terbatas dalam segi tempat dan waktu (Hidayah, Adawiyah, \& Mahanani, 2020). Masalah tersebut menjadi sebuah beban tersendiri bagi beberapa banyak peserta didik di SMA Negeri 1 Bringin, dimana mereka sulit mencari teman berdiskusi dirumah mengenai sebuah tugas yang diberikan oleh pendidik dikarenakan mayoritas pekerjaan orang tuanya menjadi buruh pabrik maupun petani yang sulit memantau mereka dan menjadi teman diskusi pada saat penugasan materi. Selain tugas tertulis, dalam pembelajaran agama islam juga memiliki tugas terstruktur berupa praktik namun melalui media online. Peserta didik juga mengalami rasa lelah yang sangat berat dikarenakan adanya tugastugas yang banyak. Tugas yang sangat banyak tadi sangat kurang efektif dalam pelaksanaan pembelajaran online bagi peserta didik, sebab hal tersebut tidak menggambarkan sebuah pembelajaran yang bermakna sesuai petunjuk Menteri Pendidikan (Fahruni, 2021). Hal tersebut menjelaskan bahwa masih ada beberapa peserta didik yang merasakan beban berlipat ganda dalam melakukan tugas praktik keagamaan, dimana terkadang tugas praktik tersebut harus di posting dalam media sosial. Mereka harus melakukan beberapa langkah dan prosedur lebih seperti merekam praktik mereka agar menjadi sebuah video, berbeda dengan saat tatap muka yang menjadikan peserta didik dapat mengerjakan tugas berupa mempraktikkan materi keagamaan secara langsung tanpa perantara sebuah media berbasis virtual.

Kelima, minimnya dorongan spiritual dari pendidik berjumlah 0,7\%. Pendidik mempunyai peran yang penting sekali bagi peserta didik dalam mengajarkan semua materi yang telah dikuasainya, selain itu seorang pendidik juga memiliki beban moral yang amat tinggi, hal itu diwujudkan dalam bentuk memberikan motivasi pada peserta didik supaya semangat dalam belajar dan memberikan contoh yang baik dalam berperilaku serta menjalin pergaulan di masyarakat. Dalam bidang Pendidikan agama islam, seorang pendidik wajib mampu membimbing, mengarahkan, dan mengembang tumbuhkan kecerdasan emosional serta spiritual mereka pada zaman dimana banyaknya teknologi-teknologi canggih agar mampu menyaring hal positif yang ada pada arus globalisasi. Membangun spiritual peserta didik memiliki berbagai tujuan positif seperti menumbuhkan kesadaran dan pengetahuan peserta didik dalam mengeksplorasi kemampuan nilai spiritual dalam dirinya. Peserta didik akan memiliki perilaku yang negatif seperti tindakan kriminal apabila tidak mampu mengontrol spiritualnya. Namun berbeda halnya dengan peserta didik yang mampu mengelola spiritualnya, mereka akan mampu mengatasi masalah yang ringan hingga berat seperti mampu mmengatasi rasa stress dan depresi (Holil, 2018). Seorang pendidik juga harus memiliki sifat kasih sayang dan perhatian yang cukup pada peserta didik dalam pembelajaran sehingga pendidik akan diperhatikan secara penuh dan seksama, terlepas dari itu semua seorang pendidik harus memiliki perhatian paling utama dalam bidang akidah (Arisanti, 2017).

Kebiasaan peserta didik di masa pandemi adalah berdiam diri dirumah dan banyak menghabiskan waktunya dengan bermain game, hal itu ditemukan pada peserta didik di SMA Negeri 1 Bringin yang kebanyakan langsung diutarakan oleh orang tua mereka. Selain itu, mereka juga tidak disiplin dalam menjalankan ibadah karena sudah nyaman dengan bermain game online. Hal tersebut membuat spiritual seseorang mengalami penurunan yang mana mengakibatkan ketenangan dan kebahagiaan jiwa menjadi berkurang. Padahal dalam dunia pendidikan, motivasi dari seorang pendidik bagi peserta didik sangatlah penting, apalagi dalam hal ini yang diajarkan adalah materi keagamaan. Para pendidik memiliki kewajiban untuk memberikan dorongan spiritual berupa nasihat keagamaan serta do'a yang dapat membantu memberikan rasa tenang pada peserta didik.

Problematika pembelajaran pendidikan agama islam melalui Microsoft teams di SMA Negeri 1 Bringin yang paling banyak dihadapi oleh peserta didik adalah kesulitan memahami 
materi melalui virtual meeting, dimana mereka kesulitan dalam mencermati materi yang di paparkan melalui platform online. Kebiasaan memahami materi secara langsung dengan carat atap muka menjadi kunci utama peserta didik untuk mampu menghayati nilai-nilai keagamaan pada materi yang disampaikan hingga mampu mempraktikkannya, dikarenakan saat pembelajaran tatap muka mereka bisa langsung melakukan kegiatan interaktif dan diskusi dengan teman maupun pendidik secara langsung. Namun pada masa pandemi seperti sekarang ini, mereka harus memahami materi secara virtual meeting yang mana hal tersebut menyebabkan timbulnya kesulitan dan kesusahan bagi peserta didik dalam mencermati, menghayati serta mempraktikkan materi pendidikan agama islam yang sudah disampaikan oleh pendidik.

\section{KESIMPULAN}

Problematika yang dihadapi peserta didik dalam proses pembelajaran pada masa pandemi ini sangatlah beragam, dimana beberapa problematika tersebut telah ditemukan di SMA Negeri 1 Bringin, khususnya dalam pembelajaran pendidikan agama islam melalui Microsoft teams seperti adanya kesulitan memahami materi melalui virtual meeting oleh peserta didik, tidak mempunyai laptop atau smartphone, merasa terbebani dengan tugas keagamaan yang bersifat praktik, terkendala sinyal atau jaringan, minimnya dorongan spiritual dari pendidik, tidak memahami penggunaan aplikasi Microsoft teams, kurangnya motivasi dan peran serta dari orang tua dan timbulnya rasa kemalasan karena daring atau e-learning. Namun terdapat lima masalah utama yang paling sering di alami para peserta didik di SMA Negeri 1 Bringin dalam pembelajaran pendidikan agama islam, dengan pengklasifikasian yang menyatakan bahwa problematika paling tinggi adalah kesulitan memahami materi melalui virtual meeting berjumlah 47,3\%, kemudian terkendala sinyal dan jaringan berjumlah 30,4\%, yang selanjutnya timbulnya rasa kemalasan karena daring atau e-learning berjumlah 18,9\%, serta merasa terbebani dengan tugas keagamaan yang bersifat praktik berjumlah $2,7 \%$, dan problematika yang terakhir adalah minimnya dorongan spiritual dari pendidik berjumlah $0,7 \%$.

Berdasarkan beberapa problematika diatas, kita sebagai pendidik harus mampu membuat dan membangun konsep serta suasana pendidikan yang efektif serta fleksibel dengan keadaan yang sedang dihadapi, dimana pada zaman modern ini banyak ditemukan metode pembelajaran serta media yang dapat digunakan dalam kegiatan belajar mengajar. Namun selain menggunakan berbagai metode maupun media masa kini, diharapkan seorang pendidik khususnya pendidik agama islam tetap mampu menjaga eksistensi dan tujuan utama dalam pembelajaran serta mampu menciptakan suasana yang menyenangkan dalam pembelajaran serta membangun intelektual dan spiritual peserta didik supaya dimasa depan mampu mencetak generasi yang pandai dalam bidang teknologi, keagamaan dan tidak terlepas dari nilai-nilai luhur bangsa dan negara. Di wajibkan juga bagi pendidik untuk memahami kendala-kendala yang dialami peserta didik dengan tidak memandang masalah hanya sebatas pandangan pribadi melainkan yang benar-benar sedang terjadi dilapangan, selain itu seorang pendidik juga harus mampu menjadi sosok yang inspiratif dan teladan bagi peserta didik serta mampu membimbing dan mengembangkan kecerdasan, emosional serta spiritual mereka dalam bentuk implementasi lahiriyah maupun batiniyah.

\section{DAFTAR PUSTAKA}

Adisel, Adisel, and Ahmad Gawdy Prananosa. "Penggunaan Teknologi Informasi dan Komunikasi dalam Sistem Manajemen Pembelajaran pada Masa Pandemi Covid 
19." ALIGNMENT: Journal of Administration and Educational Management 3.1 (2020): 1-10.

Ali, Akbar. "UPAYA GURU PAI DALAM MENINGKATKAN MOTIVASI BELAJAR SISWA PADA MATA PELAJARAN PAI DI SMK SYUHADA TEKNOLOGI BANJARMASIN." (2015).

Ali, Mohammad. "Penelitian pendidikan dan prosedur strategi." Bandung: Angkasa (1987).

Alqurashi, Emtinan. "Predicting student satisfaction and perceived learning within online learning environments." Distance Education 40.1 (2019): 133-148.

Arisanti, Devi. "Implementasi pendidikan akhlak mulia di SMA Setia Dharma Pekanbaru." Jurnal Pendidikan Agama Islam Al-Thariqah 2.2 (2017): 206-225.

Bali, Muhammad Mushfi El Iq, and Musrifah Musrifah. "The Problems of Application of Online Learning in the Affective and Psychomotor Domains During the Covid-19 Pandemic." Jurnal Pendidikan Agama Islam 17.2 (2020): 137-154.

Chiou, Hua-Huei. "The impact of situated learning activities on technology university students' learning outcome." Education+ Training (2020).

Fahruni, Findivia Egga, and Hadi Warsito. "ANALISIS FAKTOR-FAKTOR PENYEBAB PERILAKU MALAS BELAJAR DARING SAAT PANDEMI COVID-19 PADA SISWA KELAS XII SMA NEGERI 1 MENGANTI GRESIK." Jurnal BK UNESA 12.2 (2021).

Harahap, Musaddad, and Lina Mayasari Siregar. "Konsep Pendidikan Islam Dalam Membentuk Manusia Paripurna." Jurnal Pendidikan Agama Islam Al-Thariqah 2.2 (2017): 148-163.

Hidayah, Aas Aliana Futriani, Robiah Al Adawiyah, and Prima Ayu Rizqi Mahanani. "Efektivitas Pembelajaran Daring di Masa Pandemi Covid-19." JURNAL SOSIAL: Jurnal Penelitian Ilmu-Ilmu Sosial 21.2 (2020): 53-56.

Holil, Sarip Munawar. "Peran Guru Pai Dalam Mengembangkan Kecerdasan Emosional (Eq) Dan Kecerdasan Spiritual (Sq) Siswa Smp Negeri 1 Ciwaru." EDUCATOR 4.2 (2018): 95-106.

https://docs.google.com/forms/d/e/1FAIpQLSffECGaFLNh4H81ZGZ4DX8FBcCRoUwmEP cmNbtdn0QF8fyQnA/viewform

https://edu-techno.com/konten-rumah-belajar-di-microsoft-teams/

Mahmud, Dr H., and M. Si. "Metode Penelitian Pendidikan, Bandung: CV." Pustaka Setia (2011).

Majid, Abdul \& Andyani, Dian. Pendidikan Agama Islam Berbasis Kompetensi: Konsep dan Implementasi Kurikulum 2004. Bandung: PT Remaja Rosdakarya. 2004

Martin, Louis, and Dave Tapp. "Teaching with Teams: An introduction to teaching an undergraduate law module using Microsoft Teams." Innovative Practice in Higher Education 3.3 (2019).

Microsoft (2018) Welcome to Microsoft Teams [online] Available at: https://docs.microsoft.com/en-us/microsoftteams/teams-overview [Accessed 12 Desember 2020]

Nugrahani, Farida, and M. Hum. "Metode penelitian kualitatif." Solo: Cakra Books (2014).

Nurhayati, Erlis. "Meningkatkan keaktifan siswa dalam pembelajaran daring melalui media game edukasi quiziz pada masa pencegahan penyebaran covid-19." Jurnal Paedagogy 7.3 (2020): 145-150.

Putra, Ary Antony. "Konsep Pendidikan Agama Islam Perspektif Imam Al-Ghazali." Jurnal Pendidikan Agama Islam Al-Thariqah 1.1 (2016): 41-54. 
Putria, Hilna, Luthfi Hamdani Maula, and Din Azwar Uswatun. "Analisis proses pembelajaran dalam jaringan (daring) masa pandemi covid-19 pada guru sekolah dasar." Jurnal Basicedu 4.4 (2020): 861-870.

Rigianti, Henry Aditia. "Kendala Pembelajaran Daring Guru Sekolah Dasar Di Banjarnegara." Elementary School: Jurnal Pendidikan dan Pembelajaran ke-SDan 7.2 (2020).

Sedarmayanti, Syarifudin Hidayat. "Metodologi Penelitian, Bandung: CV." Mandar Maju (2002).

Song, William W., Anders Forsman, and Jia Yan. "An e-curriculum based systematic resource integration approach to web-based education." International Journal of Information and Education Technology 5.7 (2015): 495.

Sonia, Gina. DAMPAK LIBUR SELAMA BELAJAR DARI RUMAH AKIBAT PANDEMI COVID-19 TERHADAP PSIKOLOGIS ANAK SEKOLAH DASAR. Diss. UNIVERSITAS JAMBI, 2020.

Sugiyono. Metode Penelitian Pendidikan. Bandung: Alfabeta. 2013

Sugiyono. Metode penelitian pendidikan:(pendekatan kuantitatif, kualitatif dan $R \& D$ ). Alfabeta, 2008.

Susiana, Susiana. "Problematika Pembelajaran PAI di SMKN 1 Turen." Jurnal Pendidikan Agama Islam Al-Thariqah 2.1 (2017): 73-88.

Tabi' in, A. (2016). Kompetensi guru dalam meningkatkan motivasi belajar pada MTsn Pekan Heran Indragri Hulu. Jurnal Al-Thariqah, 1(2), 156-171.

Wahyono, Poncojari, H. Husamah, and Anton Setia Budi. "Jurnal Pendidikan Profesi Guru." Guru Profesional di Masa Pandemi COVID-19: Review Implementasi, Tantangan, dan Solusi Pembelajaran Daring 1: 51-65.

Wilatikta, Ayu. "Manajemen Kurikulum Pendidikan Agama Islam Jenjang Pendidikan Dasar: Kontekstualisasi Strategi Pembelajaran Semasa Pandemi." Ta'lim 2.2 (2020): 1-12.

Yana, Winda, and Prima Ayu Rizqi Maharani. "Tantangan Pembelajaran Virtual Di Tengah Pandemi Covid-19 Bagi Siswa Sekolah Dasar." JURNAL SOSIAL: Jurnal Penelitian Ilmu-Ilmu Sosial 21.2 (2020): 57-61. 